Int. J. Dev. Biol. 49: 885-890 (2005)

doi: $10.1387 / \mathrm{ijdb} .052037 \mathrm{ao}$

Developmental Expression Pattern

\title{
Expression of Hex during feather bud development
}

\author{
AKIKO OBINATA*,1 and YOSHIHIRO AKIMOTO \\ ${ }^{1}$ Department of Physiological Chemistry, Faculty of Pharmaceutical Sciences, Teikyo University, Sagamiko, Kanagawa, Japan and \\ ${ }^{2}$ Department of Anatomy, Kyorin University School of Medicine, Mitaka, Tokyo, Japan
}

\begin{abstract}
We studied proline-rich divergent homeobox gene Hex/Prh expression in the dorsal skin of chick embryo during feather bud development. Hex mRNA expression was first observed in the dorsolateral ectoderm and mesenchyme at 5 days, then in the epithelium and the dermis of the dorsal skin before placode (primordium of feather bud) formation and then was restricted to the placode and the dermis under the placode. Afterward, Hex expression was seen in the epidermis and the dermis of the posterior region of short bud. In accordance with Hex mRNA expression in the placode, Hex protein was observed in the epidermis as well as in the dermis of the placode. Immunoelectron microscopic study indicated that the protein located both in the nuclei and cytoplasm of the epidermis and the dermis at the short bud stage. The Wnt signaling pathway plays an essential role in the early inductive events in hair (Wnt3a and 7a) and feather (Wnt7a) follicles. The pattern of Hex expression in the epidermis was similar to that of Wnt7a, while little, if any, expression of Wnt7a was detected in the dermis under the placode or the dermis of the short bud compared with that of $\mathrm{Hex}$, suggesting that Hex plays an important role in the initiation of feather morphogenesis.
\end{abstract}

KEY WORDS: Hex, homeobox gene, feather placode, Wnt, feather bud development

Epithelial appendages including feathers, scales, hair, claws, teeth, etc are induced and shaped through epithelial-mesenchymal interactions (Smola etal., 1993; Chuong etal., 1996; Kishimoto et al., 2000). An inductive signal from the dermis initiates formation of epidermal placodes that, in turn, induce dermal condensation in the underlying dermis (reviewed in Sengel,1976). Several molecules that mediate inductive signaling during hair and feather tract formation have been identified, including Wnts (Widelitz et al., 1999; Noramly et al., 1999; Huelsken et al., 2001; Andl et al., 2002), bone morphogenetic protein (BMP) in early skin development (Scaal et al., 2002), BMP inhibitor at placode stages (Patel et al., 1999), fibroblast growth factors (FGFs)(Widelitz et al., 1996; Song et al., 1996), Hedgehog (Ting-Berreth and Chuong, 1996) and Notch/Delta families (Crowe et al., 1998; Viallet et al., 1998). Notch/Delta signals refine the patterning of the feather placode (Crowe et al., 1998).

Homeobox genes are a large family of transcription factors which plays a fundamental role in cell differentiation during development (Gehring et al., 1994). Abnormal hair follicles were observed in transgenic mice overexpressing homeobox gene Msx-2 (Jiang et al., 1999). Hair defects were observed in Hoxc13 mutant mice (Godwin and Capecchi, 1998) and Jave-Suarez et al., (2002) showed direct involvement of HOXC13 in the regulation of human hair keratin gene expression. The divergent homeobox genes Msx1 (Noveen et al., 1995), Gbx1 (Obinata et al., 2001) and HB9 (Kosaka et al., 2000a,b) are expressed in skin and its appendages, such as hair, feather or scale and appear to be candidates for the regulation of the development of these tissues. Another divergent homeobox gene Hex is expressed during early stages of chick embryogenesis, including pharyngeal endoderm, endocardium, liver, thyroid gland primordia and blood islands (Yatskievych et al., 1999). Hex is required for forebrain, thyroid and liver formation and blood differentiation (Keng et al., 2000; Martinez-Barbera et al.2000; Martinez-Barbera \& Beddington 2001). In liver morphogenesis, Hex expression in avian anterior lateral endoderm is regulated by autocrine BMP signaling (Zhang et al., 2002). We showed previously that Hex is expressed in chick embryonic tarsometatarsal skin and regulates epidermal cell proliferation (Obinata et al., 2002). In this study, to examine whether the Hex gene is involved in the feather morphogenesis or not, we performed in situ hybridization and immunostaining analyses spatially and temporally in dorsal skin of chick embryo.

Expression pattern of Hex during feather bud development To see the localization of Hex during feather bud development, we performed an in situ hybridization analysis in developing chick. Hex expression was seen in the dorsolateral mesenchyme

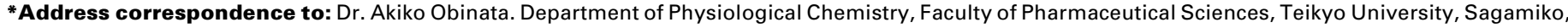
Kanagawa 199-0195, Japan. Fax: +81-426-85-3744. email: akiobi@pharm.teikyo-u.ac.jp
} 

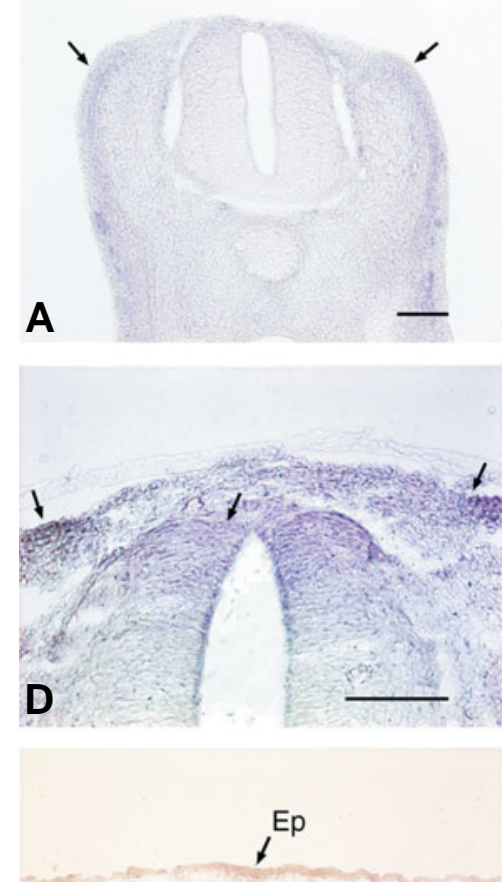

De

$\mathbf{F}$
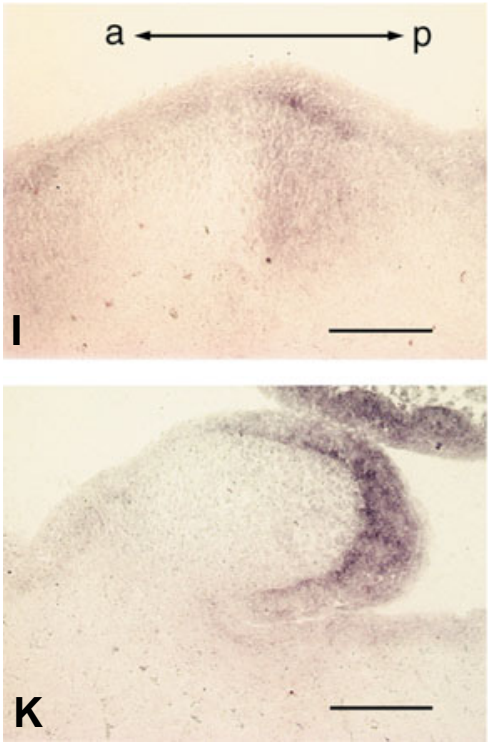
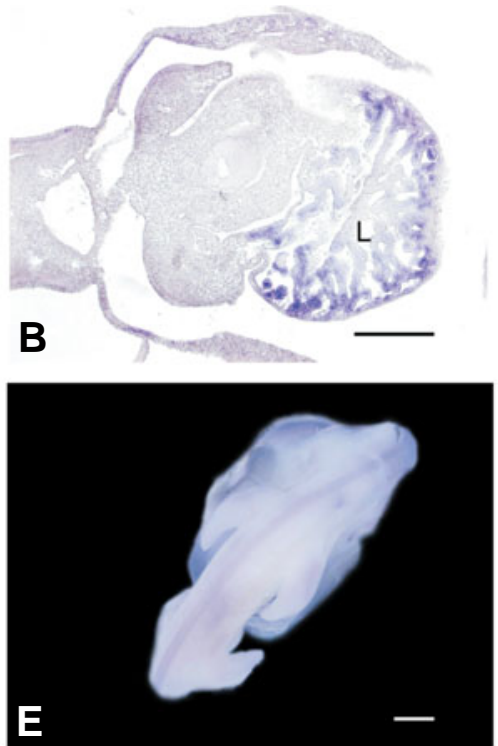

C
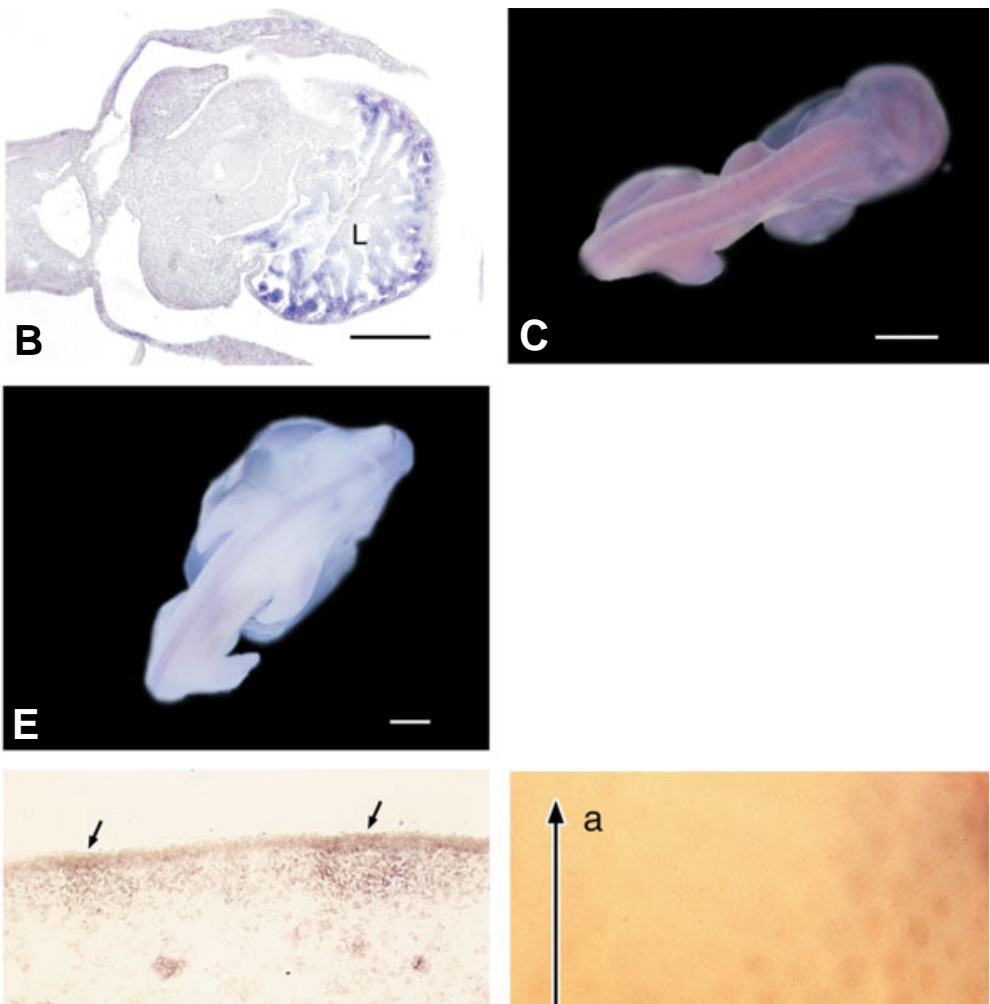

G

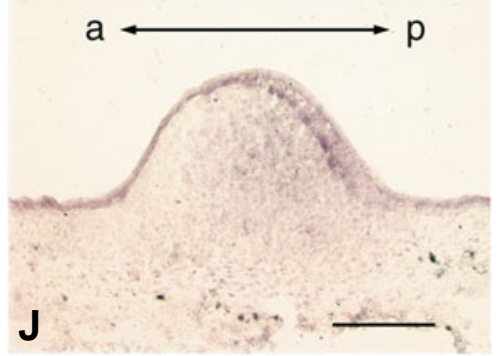

H
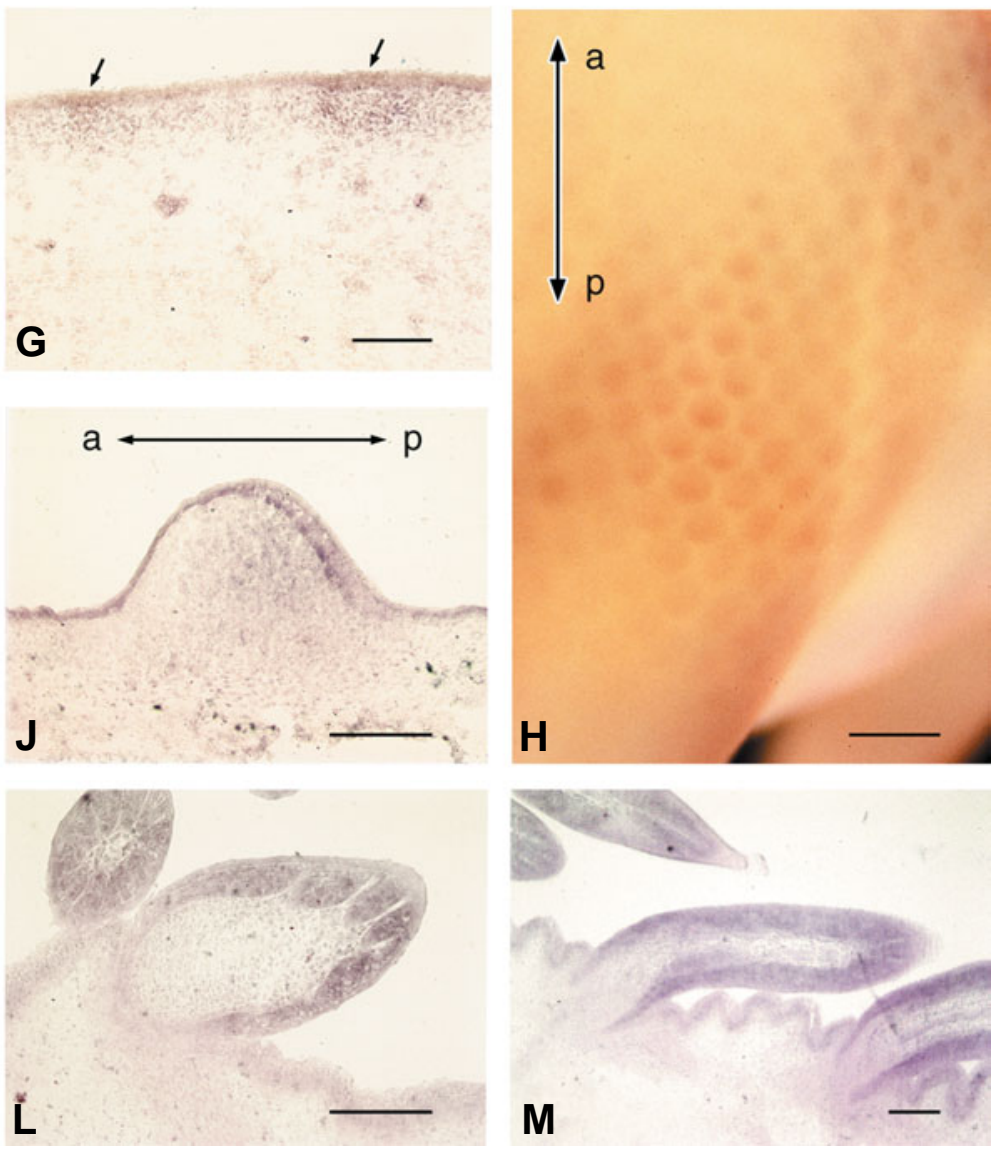
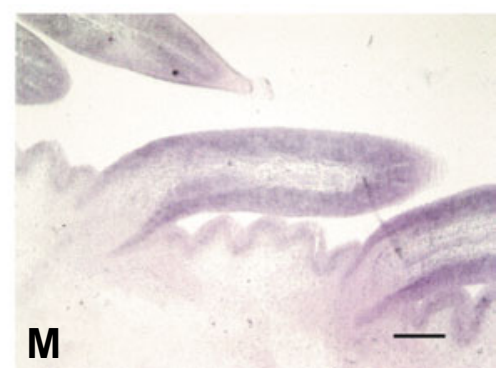

Fig. 1. Expression pattern of Hex mRNA during feather development as revealed by in situ hybridization. Transverse sections $(A, B, D)$ through the dorsal ectoderm and trunk region of chick embryos and whole embryo $(C, E, H)$ after whole mount in situ hybridization (WISH)(A-E, H). Hex expression is seen in the dorsolateral region (arrows) of the mesenchyme, if any, (A,C) and is strong in liver (L) (B) at 4 days. The expression is seen from the dorsolateral to dorsomedial region (arrows) of the ectoderm and mesenchyme (D,E) at 5 days. Cryostat sections (F, G,I-M). Hex expression is seen through the epidermis (Ep) while the expression was very little in the dermis (De) of the dorsal skin before placode formation (F) at 6 days and is restricted to the epidermis and dermis of the placode region (arrows) (G) at 7 days. Later, at short bud stage, the stronger expression is seen in both the epidermis and the dermis at the posterior buds (I, $\mathbf{J})$. At long bud stage, the signal is stronger in the epidermis than in the dermal cells in the posterior bud (K-M). In WISH (H), as well as in cryostat sections, Hex gene expression is detectable in feather buds with stronger signal in posterior regions, but not in interbud regions in 8-day-old chick embryo. a, anterior; p, posterior. Bars, $100 \mu \mathrm{m}$ in A,D,F,G,I-M; $500 \mu \mathrm{m}$ in $B ; 1 \mathrm{~mm}$ in C,E; $2 \mathrm{~mm}$ in $\mathrm{H}$. 

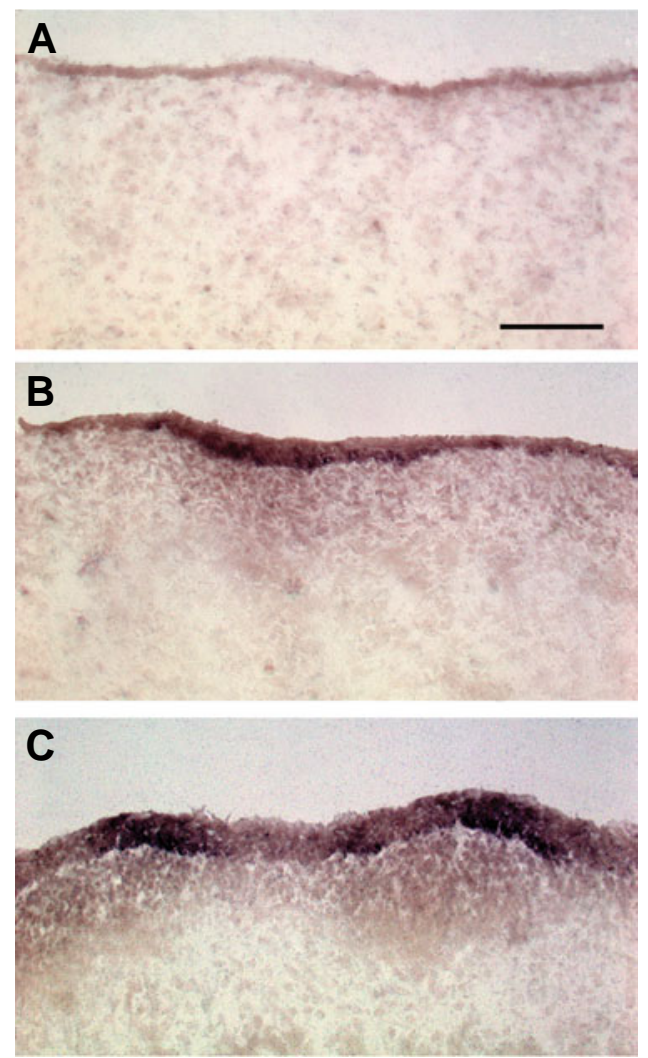

Fig. 2. Expression pattern of Wnt7a mRNA during feather development as revealed by in situ hybridization. Sections of dorsal skin from 6-to 8-day-old chick embryos (A-C). Wnt7a expression is seen through the epidermis before placode formation (A) at 6 days and the stronger signal is seen in the epidermis of the placode region (B) at 7 days. At late placode stage, the stronger signal is seen in the epidermis of the posterior buds (C). Bar, $50 \mu \mathrm{m}$. (arrows) (Fig. $1 \mathrm{~A}, \mathrm{C}$ ), but was strong in liver (B) at 4 days. The expression was seen from the dorsolateral to dorsomedial region (arrows) of the ectoderm and mesenchyme at 5 days (Fig. $1 \mathrm{D}, \mathrm{E}$ ). Hex expression was seen through the epidermis of the dorsal skin before placode formation at 6 days while the expression was very little in the dermis (Fig. 1F) and is restricted to the placode epithelium and the dermis underneath the placode at 7 days (Fig. $1 \mathrm{G})$. Later, at short bud stage, stronger Hex expression was seen in both the epidermis and the dermis of the posterior bud (Fig. 1 $\mathrm{H}, \mathrm{I}, \mathrm{J})$. At long bud stage, the signal was stronger in the epidermis than in the dermis at the distal region of the bud (Fig. $1 \mathrm{~K}, \mathrm{~L}$ ) and later an intense signal in the dermis at the bottom region of the bud adjacent to the epidermis was also seen (Fig. $1 \mathrm{M}$ ). Surprisingly, the Wnt7a expression pattern in the epithelium (Fig. 2 A,B,C and Widelitz et al., 1999) was almost similar to that of Hex (Fig. 1 F,G,I), while less expression of Wnt7a in the dermis relative to that of the epidermis was observed under the placode (compare Fig. 1G with Fig. 2C).

\section{Immunohistochemical localization of Hex protein during feather bud development}

To know whether Hex mRNA and Hex protein are expressed correlatively and Hex locates in nucleus as a transcription factor during feather bud development, we used two different kinds of antiserum. One is antiserum raised against glutathione S-transferase fusion protein containing the $76 \mathrm{COOH}$-terminal amino acids of mouse Hex (Ghosh et al., 2000), which was

Fig. 3. Western blot and immunohistochemical staining of Hex protein during feather development. Whole-cell lysates $(50 \mu \mathrm{g})$ obtained from HeLa cells transfected with Hex-pcDLSR $\alpha$ (A) and chick embryonic tissues (B). See text for details. Numbers used at the left side indicate molecular weights. Hex protein is detected by anti-N-terminal chick Hex antiserum followed by Cy3-conjugated secondary antibody (C-F). Hex was observed through the epidermis and the dermis with a stronger immunoreactivity at the placode (C) and the short bud (D,E), while less immunoreactivity was observed in the dermis (C,D,E). At the long bud stage, the immunoreactivity was seen throughout the epidermis and the periderm at the bud with a stronger immunoreactivity in the peridermal cells and the dermis at the root regions of the bud (F). Bar, $50 \mu \mathrm{m}$.
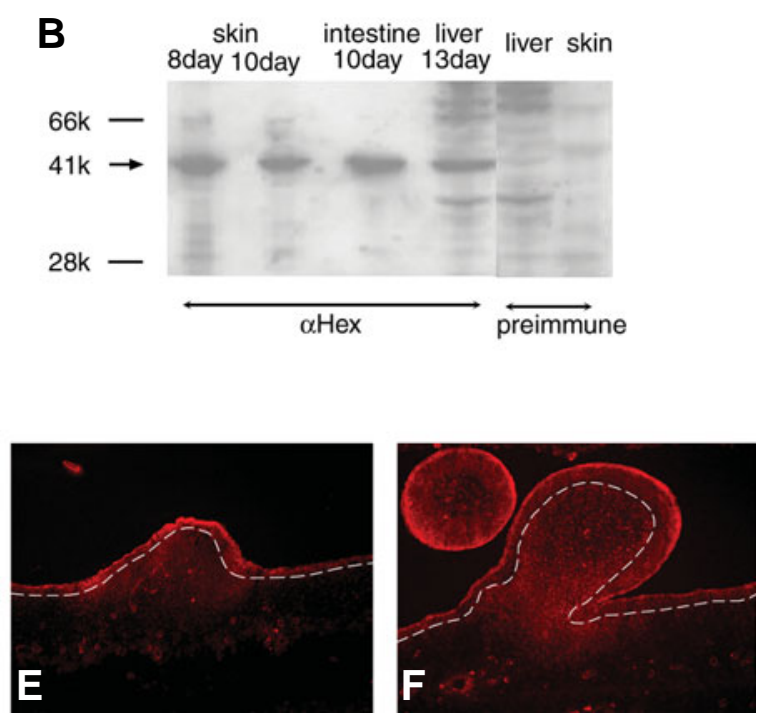
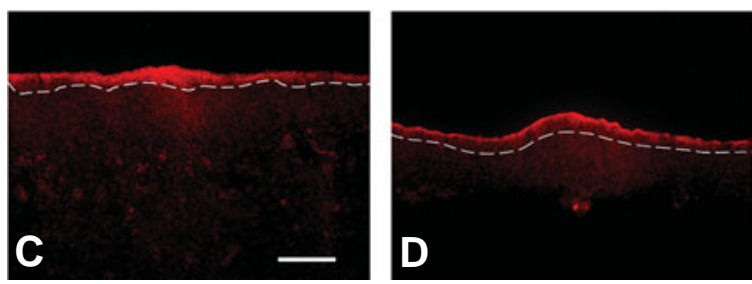

E 

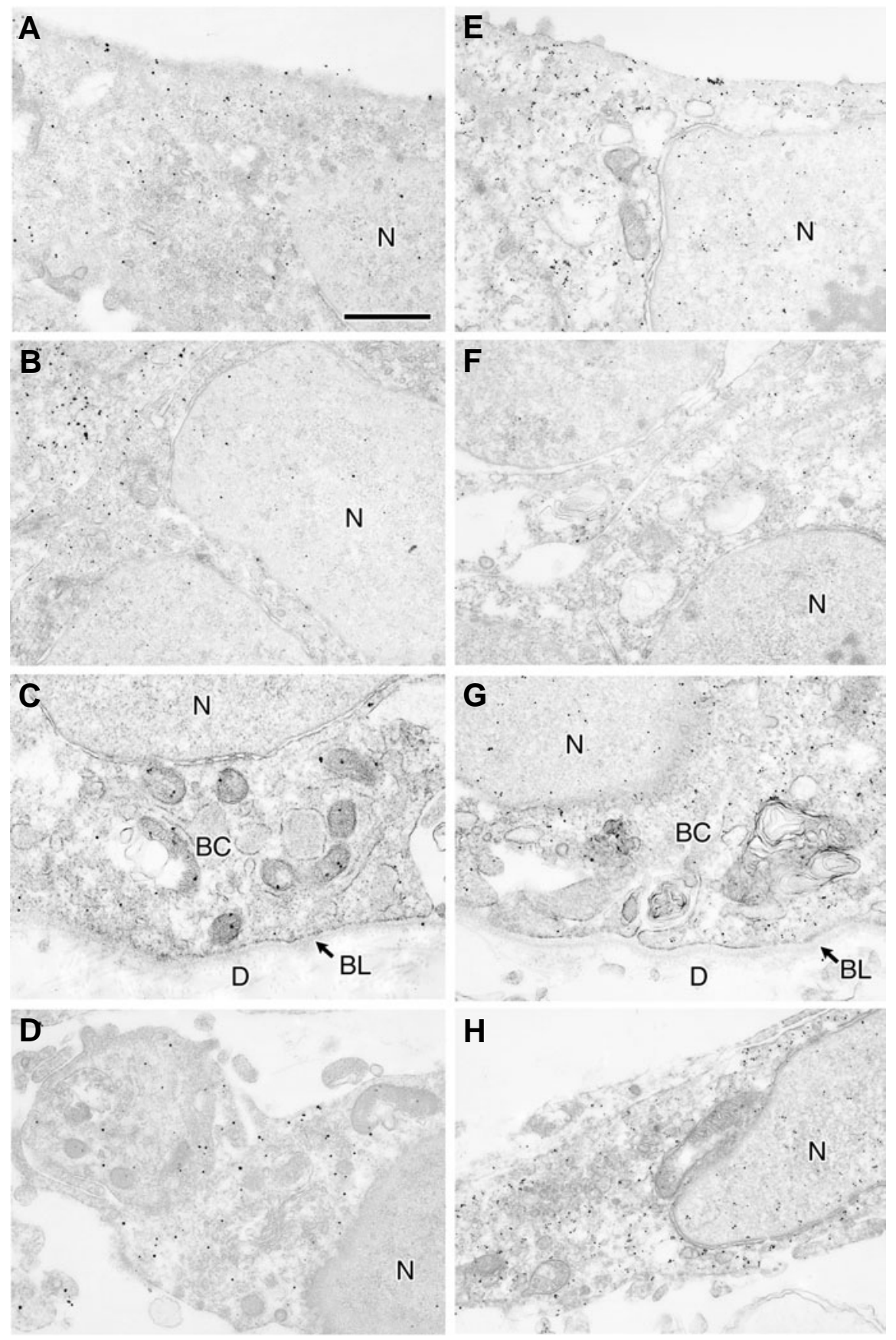

Fig. 4. Immunoelectron microscopic study of feather bud at 10 days. Anti-N-terminal chick Hex antiserum (A-D) and antibody against glutathione S-transferase fusion protein containing the $76 \mathrm{COOH}$-terminal amino acids of mouse Hex (E-H) were used. Colloidal gold labeling represents the localization of Hex in the epidermal cells of superficial layer $(\mathbf{A}, \mathbf{E})$, intermediate layer $\mathbf{( B , F )}$, basal layer $\mathbf{( C , G )}$ and in the dermal fibroblasts (D,H). Both antibodies indicated the same localization pattern in nucleus and cytoplasm of the epidermis and the dermis in the bud at 10 days with stronger immunoreactivity in the cytoplasm (A-H). BC, basal cell of epidermis; $B L$, basal lamina; $D$, dermis; $N$, nucleus. Bar, $1 \mu \mathrm{m}$.

that of its mRNA, the extent of their expression level was different. The periderm is sloughed at later stages in the development. To study more precisely about the localization of the Hex in the cell, immunoelectron microscopic study was performed with 2 different kinds of Hex antibody. Colloidal gold labeling represents the localization of Hex in the epidermal cells of superficial layer (Fig. 4 A,E), intermediate layer (Fig. 4 B,F), basal layer (Fig. 4 C,G) and in the dermal fibroblasts (Fig. $4 \mathrm{D}, \mathrm{H}$ ) of the long bud at 10 days. Both antibodies indicated the same localization pattern in nucleus and cytoplasm of the epidermis and the dermis with stronger immunoreactivity in the cytoplasm (Fig. 4 A-H). Few colloidal gold labeling was observed in the skin without first antibody (Fig. 5).

In this study, we showed that Hex was expressed as early as at 5 days in chick embryonic dorsolateral skin and then diffusely distributed in skin before placode formation and that its expression was restricted to the placode and the dermis under the placode and later in the epidermis and the dermis of the posterior region of the short bud. The Hex protein localized both in nucleus and cytoplasm of the epidermis and the dermis at the long bud stage with stronger expression in the cytoplasm, suggesting Hex might be actively sequestered in the cytoplasm, either by preventing nuclear import or by promoting a balance of export over import signals, or have a potential for intercellular trafficking by conventional secretion as in the case of Engrailed

kindly provided by Dr C.Bogue. The other is anti-N-terminal chick Hex antiserum. By Western blots, they developed a specific strong immune response against a $41 \mathrm{k}$ dalton band of Hex recombinant protein (Fig. 3A), the homogenate of chick embryonic dorsal skin, intestine, liver (Fig. 3B), or 5-day-old whole embryo (data not shown). At placode stage and later, Hex was observed throughout the epidermis with a stronger expression at the placode and bud region and in the dermis under these regions (Fig. $3 \mathrm{C}-\mathrm{E}$ ). At the long bud stage, the immunoreactivity was seen at the bud with a stronger immunoreactivity in the peridermal cells and the dermal cells at the root regions of the bud (Fig. 3F). It is interesting to note that, while tissue localization of Hex protein was correlated with homeoprotein (Maizel et al.2002) or CVC paired-like homeobox proteins (Knauer etal., 2005). The meaning of Hex existence in the cytoplasm must be studied in future. Surprisingly, the pattern of Hex expression in the epidermis was similar spatially and temporally to that of Wnt7a expression. The Wnt/Wg signaling pathway reviewed in Wodarz \& Nusse, (1998) plays an essential role in the early inductive events in hair and feather follicles (Widelitz et al., 1999; Huelsken et al., 2001; Andl et al., 2002) and even in its equivalent (denticle) of fly (Dai et al., 1998; Payre et al., 1999; Li et al., 2002) and in many aspects of development such as the tooth (Dassule \& McMahon,1998), limb bud (Cygan et al., 1997), lung (Shu et al., 2002), mammary gland (Humphreys et al., 1997), 


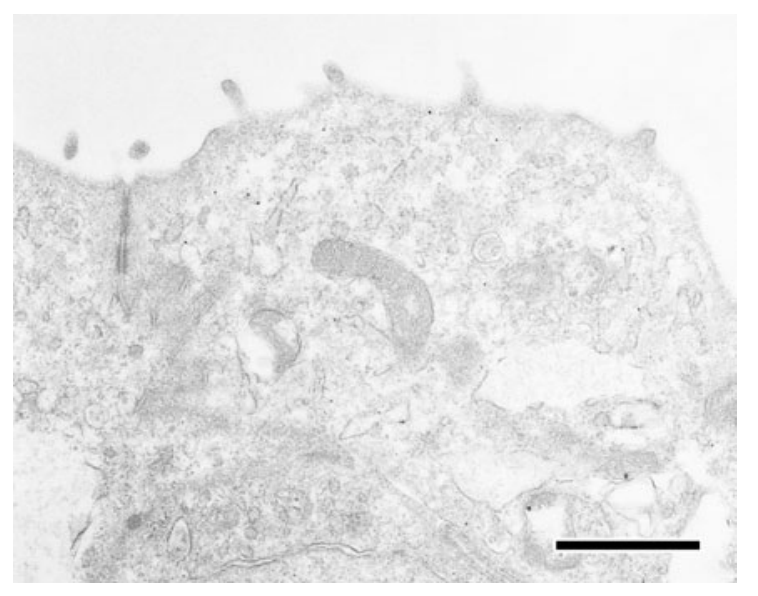

Fig. 5. Cytochemical control. Immunoelectron microscopic study of the superficial layer of feather bud at 10 days. To check the specificity, antichick Hex antiserum was replaced with normal rabbit serum. Scarce colloidal gold labeling was observed. Bar, 1 um.

kidney(Torres \& Nelson 2000) and liver (Suksaweang et al., 2004). Recent studies have now addressed the issue of whether Hex is involved in the Wnt7a signaling pathway or in the initiation of feather bud formation (Obinata and Akimoto, 2005).

\section{Experimental Procedures}

\section{Preparation of a digoxigenin (DIG)-labeled RNA probe}

The Hex RNA probe was prepared as described previously (Obinata et al., 2002). For synthesis of a Wnt $7 a$ RNA probe, a Wnt7a cDNA fragment containing the entire coding region, which was kindly provided by $\mathrm{Dr}$ T.Nohno (Kawakami et al., 2000), was amplified and prepared using a standard protocol.

\section{In situ hybridization.}

In situ hybridization with the DIG-labeled probe was performed as described previously (Kosaka et al., 2000a).

\section{Transgene construction}

A full-length Hex cDNA containing the entire Hexcoding region, which was generously provided by Dr G.Goodwin (Haddow Labolatories, Institute of Cancer Research, Sutton,UK), was constructed with pcDLSR $\alpha$.

\section{Lipofection}

HeLa cells were transfected with Hex -pcDLSR $\alpha$ using TransIT-LT1 Transfection Reagent (Invitrogen, California, USA) according to the manufacturer's instructions.

\section{Western blotting}

A rabbit antiserum was generated against a $\mathrm{KLH}$-conjugated chick Hex $\mathrm{NH} 2$ peptide (MQYQAPGAAPAAALC). Western blotting was performed using standard protocols.

\section{Immunostaining for light and electron microscopy}

Frozen skin sections were processed for immunohistochemical staining as described previously (Akimoto et al.,1992; Kosaka et al., 2000b).

\section{Microscopy}

Skin explants were processed for light and electron microscopic observations as described previously (Obinata et al., 1991).

\section{Acknowledgements}

We thank Dr G.Goodwin (Haddow Laboratories, Institute of Cancer Research, Sutton, UK), for providing a chick Hex cDNA; Dr.C.Bogue (Department of Pediatrics, Yale University, School of Medicine, New Haven, Connecticut) for providing a Hex polyclonal antibody and Dr T.Nohno (Departmennt of Molecular Biology, Kawasaki Medical School, Kurashiki, Japan) for providing chickWnt7a cDNA. We are grateful to Ms. S.Matsubara and Ms. T.Shibata for their technical support. This work was supported, in part, by Grants-in-Aid from the Ministry of Education, Science, Sports, Culture and Technology, Japan.

\section{References}

AKIMOTO, Y., OBINATA, A., ENDO, H. and HIRANO, H. (1992). Immunohistochemical study of basement membrane reconstruction by an epidermisdermis recombination experiment using cultured chick embryonic skin: Induction of tenascin. J. Histochem. Cytochem. 40: 1129-1137.

ANDL, T., REDDY, S.T., GADDAPARA, T. and MILLAR, S.E. (2002). Wnt signals are required for the initiation of hair follicle development. Dev.Cel/ 2: 643-653.

CHUONG, C.-M., WIDELITZ, R.B., TING-BERRETH, S. and JIANG, T.-X. (1996). Early events during avian skin appendage regeneration: Dependence on epithelial-mesenchymal interaction and order of molecular reappearance. J.Invest.Dermatol. 107: 639-646.

CROWE, R., HENRIQUE, D., ISH-HOROWICZ, D. and NISWANDER, L. (1998). A new role for Notch and Delta in cell fate decisions: patterning the feather array. Development 125: 767-775.

CYGAN, J.A., JOHNSON, R.L. and MCMAHON, A.P. (1997). Novel regulatory interactions revealed by studies of murine limb pattern in Wnt-7a and En-1 mutants. Development 124: 5021-5032.

DAI, X., SCHONBAUM, C., DEGENSTEIN, L., BAI, W., MAHOWALD, A. and FUCHS, E. (1998). The ovo gene required for cuticle formation and oogenesis in flies is involved in hair formation and spermatogenesis in mice. Genes Dev. 12: 3452-3463.

DASSULE, H.R. and MCMAHON, A.P. (1998). Analysis of epithelial-mesenchymal interactions in the initial morphogenesis of the mammalian tooth. Dev. Biol. 202: 215-227.

GEHRING, W.J., AFFOLTER, M. and BUURGLIN, T. (1994). Homeodomain proteins. Annu.Rev.Biochem.63: 487-526.

GHOSH, B., GONEA, G.R., DENSON, L.A. IANNUCCI, R., JACOBS, H.C. and BOGUE, C.W. (2000). Immunocytochemical characterization of mucine Hex, a homeobox-containing protein. Pediatr.Res. 48: 634-638.

GODWIN, A.R. and CAPECCHI, M.R. (1998). Hoxc13 mutant mice lack external hair. Genes Dev. 12: 11-20.

HEADON, D. and OVERBEEK, P.A. (1999). Involvement of a novel Tnf receptor homologue in hair follicle induction. Nature Genetics 22: 370-374.

HUELSKEN, J., VOGEL, R., ERDMANN B., COTSARELIS, G. and BIRCHMEIER, W. (2001). $\beta$-catenin controls hair follicle morphogenesis and stem cell differentiation in the skin. Cell 105: 533-545.

HUMPHREYS, R.C., LYDON, J., O'MALLY, B.W. and ROSEN, J.M. (1997) Mammary gland development is mediated by both stromal and epithelial progesterone receptors. Mol.Endocrinol. 11: 801-811.

JAVE-SUAREZ, LF., WINTER, H., LANGBEIN, L., ROGERS, MA. and SCHWEIZER, J. (2002). HOXC13 is involved in the regulation of human hair keratin gene expression. J.Biol.Chem. 277: 3718-3726.

JIANG, T.X., LIU, Y.H., WIDELITZ, R.B. MAXON, R.E. AND CHUONG, C.M. (1999). Epidermal dysplasia and abnormal hair follicles in transgenic mice overexpressing homeobox gene Msx-2. J.Invest.Dermatol. 113: 230-237.

KAWAKAMI, Y., WADA, N., NISHIMATSU, S. and NOHNO, T. (2000). Involvement of frizzled-10 in Wnt-7a signaling during chick limb development. Dev.Growth Differ. 42: 561-569.

KENG, V.W., YAGI, H., IKAWA, M., NAGANO, T., MYNTZ, Z., YAMADA, K., TANAKA, T., SATO, A., MURAMATSU, I., OKABE, M., SOTO, M. and NOGUCHI, T. (2000). Homeobox gene Hex is essential for onset of mouse embryonic liver development and differentiation of the monocyte lineage. Biochem.Biophys. Res. Comm.276: 1155-1161. 
KISHIMOTO, J., BURGESON, R.E. and MORGAN, B.A. (2000). Wnt signaling maintains the hair-inducing activity of the dermal papilla. Genes Dev. 14: 11811185.

KNAUER, S.K., CARRA, G. and STAUBER, R.H. (2005). Nuclear export is evolutionarily conserved in CVC paired-like homeobox proteins and influences protein stability, transcriptional activation and extracellular secretion. Mol.Cell. Biol. 25: 2573-2582.

KOSAKA, Y., AKIMOTO, Y., OMOTO, Y., OBINATA, A. and HIRANO, H. (2000a). Expression of the HB9 homeobox gene concomitant with proliferation accompanying epidermal stratification during development of chick embryonic tarsometatarsal skin. Histochem.J. 32: 275-280.

KOSAKA, Y., AKIMOTO, Y., OBINATA, A. and HIRANO, H. (2000b). Localization of HB9 homeobox gene mRNA and protein during the the early stages of chick feather development. Biochem.Biophys.Res.Commu. 276: 1112-1117.

LI, B., MACKAY, D.R., DAI, Q., LI, T.W.H., NAIR, M., FALLAHI, M., SCHONBAUM, C.P., FANTES, J., MAHOWALD, A.P., WATERMAN, M.L., FUCHS, E. and DAI, $X$. (2002). The LEF1/ $\beta$-catenin complex activates movo1, a mouse homolog of Drosophila ovo required for epidermal appendage differentiation. Pros.Natl.Acad.Sci.USA 99: 6064-6069.

MAIZEL, A., TASSETTO, M., FIHOL, O., COCHET, C., PROCHIANTZ, A. and JOLIOT, A. (2002). Engrailed homeoprotein secretion is a regulated process. Development 129: 3545-3553.

MARTINEZ-BARBERA, J.P. and BEDDINGTON, R.S. (2001). Getting your head around Hex and Hesx1: forebrain formation in mouse. Int.J.Dev.Biol. 45: 327336.

MARTINEZ-BARBERA, J.P., CLEMENTS, M., THOMAS, P., RODRIGUEZ, T., MELOY, D., KIOUSSIS, D. and BEDDINGTON, R.S. (2000). The homeobox gene $\mathrm{Hex}$ is required in definitive endodermal tissues for normal forebrain, liver and thyroid formation. Development 127: 2433-2445.

NORAMLY, S., FREEMAN, A. and MORGANB.A. (1999). $\beta$-catenin signaling can initiate feather bud development. Development 126: 3509-3521.

NOVEEN, A., JIANG, T-X, TING-BERRETH, S.A. and CHUONG, C-M. (1995). Homeobox genes Msx-1 and Msx-2 are associated with induction and growth of skin appendages. J.Invest.Dermatol. 104: 711-719.

OBINATA, A., AKIMOTO, Y., HIRANO, H. and ENDO, H. (1991). Stimulation by Bt2cAMP of epidermal mucous metaplasia in retinol-pretreated chick embryonic cultured skin and its inhibition by herbimycin A, an inhibitor for proteintyrosine kinase. Exp.Cell Res.193: 36-44.

OBINATA, A., AKIMOTO, Y., OMOTO, Y. and HIRANO, H. (2001). Increase in expression of the homeobox gene, $G b \times 1$, in retinol-induced epidermal mucous metaplasia. Biochem.Biophys. Res.Commu. 280: 1055-1061.

OBINATA, A., AKIMOTO, Y., OMOTO, Y. and HIRANO, H. (2002). Expression of Hex homeobox gene during skin development: Increase in epidermal cell proliferation by transfecting the Hex to the dermis. Develop.Growth.Differ. 44: 281-292.

OBINATA, A. and AKIMOTO, Y. (2005). Involvement of Hex in the initiation of feather morphogenesis. Int. J. Dev. Biol. (in press).

PATEL, K., MAKARENKOVA, H. and JUNG, H.S. (1999). The role of long range, local and direct signaling molecules during chick feather bud development involving the BMPs, follistatin and the Eph receptor tyrosine kinase Eph-A4. Mech. Dev. 86: 51-62.
PAYRE, F., VINCENT, A. and CARRENO, S. (1999). ovo/svb integrates Wingless and DER pathways to control epidermis differentiation. Nature 400: 271-275.

SCAAL, M., PROLS, F., FUCHTBAUER, E-M., PATEL, K., HORNIK, C., KOHLER, T., CHRIST, B. and BRAND-SABERI, B. (2002). BMPs induce dermal markers and ectopic feather tracts. Mech.Dev. 110: 51-60.

SENGEL, P. (1976). Morphogenesis of Skin. Cambridge University Press, Cambridge.

SHU, W., JIANG, Y.Q., LU, M.M. and MORRESEY, E.E. (2002). Wnt7b regulates mesenchymal proliferation and vascular development in the lung. Development 129: 4831-4842

SMOLA, H., THIEKOTTER, G. and FUSENIG, N.E. (1993). Mutual induction of growth factor gene expression by epidermal-dermal cell interaction. J.Cel/ Biol. 122: 417-429.

SONG, H., WANG, Y. and GOETINCK, P.F. (1996). Fibroblast growth factor 2 can replace ectodermal signaling for feather development. Proc.Nat.Acad.Sci.USA 93: 10246-10249.

SUKSAWEANG, S., LIN, C.M., JIANG, T.X., HUGHES, M.W., WIDELITZ, R.B. and CHUONG, C.M. (2004). Morphogenesis of chicken liver identification of localized growth zone and the role of beta-catenin/Wnt in size regulation. Dev.Biol. 266: 109-122.

TING-BERRETH, S. and CHUONG, C-M. (1996). Sonic hedgehog in feather morphogenesis: Induction of mesenchymal condensation and association with cell death. Dev.Dynamics 207: 157-170.

TORRES, M.A. and NELSON, W.J. (2000). Colocalization and redistribution of disheveled and actin during Wnt-induced mesenchymal morphogenesis. J.Cell Biol. 149: 1433-1442.

VIALLET, J.P., PRIN, F., OLIVERA-MARTINEZ, I., HIRSINGER, E., POURQUIE, O. and DHOUAILLY, D. (1998). Chick Delta-1 gene expression and the formation of the feather primordia. Mech.Dev. 72: 159-168.

WIDELITZ, R.B., JIANG, T.X., NOVEEN, A., CHEN, C.W. and CHUONG, C.M. (1996). FGF induces new feather buds from developing avian skin. J.Invest.Dermatol. 107: 797-803.

WIDELITZ, R.B., JIANG, T-X., CHEN, C.-W.J., STOTT, N.S. and CHUONG, C.-M. (1999). Wnt7a in feather morphogenesis:Involvement of anterior-posterior asymmetry and proximal-distal elongation demonstrated with an in vitro reconstituted model. Development 126: 2577-2587.

WODARZ, A. and NUSSE, R. (1998). Mechanism of Wnt signaling in development. Annu.Rev. Cell Dev.Biol. 14: 59-88.

YATSKIEVYCH, T.A., PASCOE, S. and ANTIN, P.K. (1999). Expression of the homeobox gene Hex during early stages of chick embryo development. Mech.Dev. 80: 107-109.

ZHANG, W., YATSKIEVYCH, T.A., CAO, X. and ANTIN, P.B. (2002). Regulation of Hex gene expression by a Smads-dependent signaling pathway. J.Biol.Chem. 277: 45435-45441.

Received: March 2005 Reviewed by Referees: April 2005 Modified by Authors and Accepted for Publication: May 2005 Edited by: Makoto Asashima 